\title{
Using hawgent dynamic mathematics software in teaching arithmetic operation
}

\author{
Lin Suan ${ }^{\mathrm{a}, 1, *}$, Zhou Ying a,2, Tommy Tanu Wijaya ${ }^{\mathrm{a}, 3}$ \\ ${ }^{a}$ Guangxi Normal University, Yucai Road, Guilin,China \\ ${ }^{1} 1440788071 @ q q . c o m ;{ }^{2} 799936971 @ q q . c o m ;{ }^{3}$ tommytanu@ foxmail.com \\ * corresponding author
}

\section{ARTICLE INFO}

Article history

Received 2020-04-15

Revised 2020-04-26

Accepted 2020-04-30

\section{Keywords}

Arithmetic operation

Elementary school

Hawgent dynamic

Mathematics software

\section{ABSTRACT}

Dynamic learning software is an auxiliary tool to help students understand the mathematical operation process. Sometimes the calculation methods of textbooks are dull and boring, an innovative teaching medium is needed to assist teaching. This research aims to create a learning medium to improve students' ability to learn rational arithmetic. The learning process will use hawgent dynamic mathematics software as the mathematics learning medium. This research designed in conjunction with the four steps of solving problems in Polya. This study involved 30 junior high school students as the research subject. The tools used in this study are cognitive tests, interviews and observations. The research results show that the use of hawgent dynamic mathematics software can improve the students' ability to operate rational numbers. This means that the realization of hawgent dynamic mathematics software in the process of mathematics learning is successful. Students are more active and enthusiastic in the classroom. In short, the development of hawgent dynamic mathematics software can improve students' rational number operation ability, because with the help of hawgent, students will increase their motivation to learn.

This is an open access article under the CC-BY-SA license.

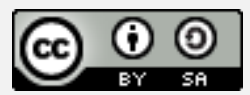

\section{Introduction}

Mathematics is a very useful subject and the foundation for learning other subjects [1-3]. Mathematics can cultivate students' logical thinking and can also develop their intelligence [4]. When learning geometric mathematics, it is very important to lay a good foundation of mathematics. As Euclid, the father of geometry, said, there is no shortcut to learning geometry. This is why the purpose of learning geometry is to lay a good foundation for students, and to extend new concepts from simple concepts, so as to establish a network of geometric knowledge, and can quickly and correctly think of the solution method when solving mathematical problems.

Mathematics is an abstract subject, so students will encounter different difficulties in different stages of learning [5-6]. Many students from primary school to junior high school will not be able to overcome the crisis from concrete thinking to abstract thinking, which will undermine students' confidence in learning mathematics and lead to the weariness of learning. In the education research in Indonesia, it is pointed out that the learning of addition and subtraction of rational numbers is one of the contents that leads to gaps among students. The study of rational numbers is a subject of junior high school students. The study found that when learning the addition and subtraction of negative numbers, it is difficult for students to understand the concept of "negative to negative [7-8]. 
Hawgent dynamic mathematical software emerged in the 1990s and was developed and implemented by a research and development team from Guangzhou. Hawgent dynamic mathematics has been focusing on the research, development, application and promotion of dynamic mathematics software, resources and courses, and it has the characteristics of intuitive, dynamic and concise [910]. It can realize the dynamic display of abstract mathematical knowledge, tracking moving point trajectory, drawing 3D images and other functions. If you have mastered the techniques used, you can infiltrate them into classroom teaching, and you can also conduct empirical research to enrich the research field of this journal. In this study, we will use the function of Hawgent dynamic mathematics software, when teaching the addition and subtraction of rational numbers, we will introduce the dynamic picture of Confucius's walk, use the picture of Confucius as the moving point, track the process of his movement, and infiltrate the addition and subtraction of rational numbers during the movement of Confucius. The algorithm of the method makes it easy for students to understand and master this knowledge point. In order to provide some reference for the teaching of rational number addition and subtraction.

\section{Method}

The research method that is use in this research is research development with the ADDIE model [11-13]. In the problem analysis stage, the introduction of problem situations helps students understand what they have learned in this lesson. In the planning stage, the researchers use hawgent dynamic mathematics software to design a problem-solving model based on the difficulties faced by students in solving the problem. The validation of product would be done by 3 media and 3 material experts. In the implementation planning stage, teachers will use the Hawgent dynamic mathematics software to teach junior high school students about the addition and subtraction of rational numbers, and regard students' reactions to hawgent as a medium of learning. In the final evaluation stage, Five of the 30 students were interviewed and expressed their opinions on the learning media and then the researchers will improve the model based on the suggestions and input of teachers and students.

In the research process, a questionnaire survey was used to investigate media experts, material experts, 30 students and 2 teachers. The researchers also interview elementary students for understand their response to hawgent as a learning media. The verification standards of media and materials experts are shown in Table 1.

Table 1. Validation criteria from media and material experts

\begin{tabular}{ccc}
\hline Percentage & Criteria & interpretation \\
\hline $76-100$ & Valid & No revision needed \\
$50-75$ & Valid enough & Fair enough/ small revision \\
$26-50$ & Less valid & A lot of revision needed \\
$0-25$ & Invalid & Total revision needed \\
\hline
\end{tabular}

The following verification standard table (Table 2) is given by junior middle school mathematics teachers when using hawgent dynamic math software.

Table 2. Validation criteria from the teachers

\begin{tabular}{ccc}
\hline Percentage & Criteria & interpretation \\
\hline $76-100$ & Valid & No revision needed \\
$50-75$ & Valid enough & Fair enough/ small revision \\
& & A few revision needed \\
$26-50$ & Less valid & A lot of revision needed \\
$0-25$ & Invalid & Total revision needed \\
\hline
\end{tabular}




\section{Results and Discussion}

\subsection{Results}

From Table 5 we can see Using hawgent dynamic mathematics software to develop a rational number learning model, it was evaluated by $85 \%$ of media experts. This means that the use of dynamic technology teaching is effective and feasible for the implementation of junior high school students. Table 3 shows the media experts' ratings of hawgent dynamic math software based on the questionnaires given.

Table 3. Assessment result from Media Expert

\begin{tabular}{ccccc}
\hline No. & Indicators & Number of item & Value & percentage \\
\hline 1. & Design and image display & 4 & 17 & $85 \%$ \\
2. & solving problem process is shown clearly & 4 & 18 & $90 \%$ \\
3. & Easiness of using the media & 4 & 17 & $85 \%$ \\
4. & How well students understand the Hawgent media & 4 & 16 & $80 \%$ \\
& Average & & $85 \%$ \\
\hline
\end{tabular}

Materials experts evaluated the hawgent dynamic math software, and the result was $84 \%$. This means that dynamic technology is effective as a learning medium for learning rational numbers and is worth testing in junior high school students. See Table 4 for the evaluation results of material experts.

Table 4. Assessment result from Material Expert

\begin{tabular}{ccccc}
\hline No. & Indicators & Number of item & Value & percentage \\
\hline 1. & Explain the definition of addition and substraction & 5 & 23 & $92 \%$ \\
2. & Explain concept & 5 & 21 & $84 \%$ \\
4. & Solve problems clearly & 5 & 19 & $76 \%$ \\
& Average & & $84 \%$ \\
\hline
\end{tabular}

\subsection{Discussion}

In the analysis phase, the researchers collected data on the difficulties faced by elementary school students in the first grade mathematics course based on the 2013 curriculum. Fig.1 shows the difficulties students face in solving rational number problems.

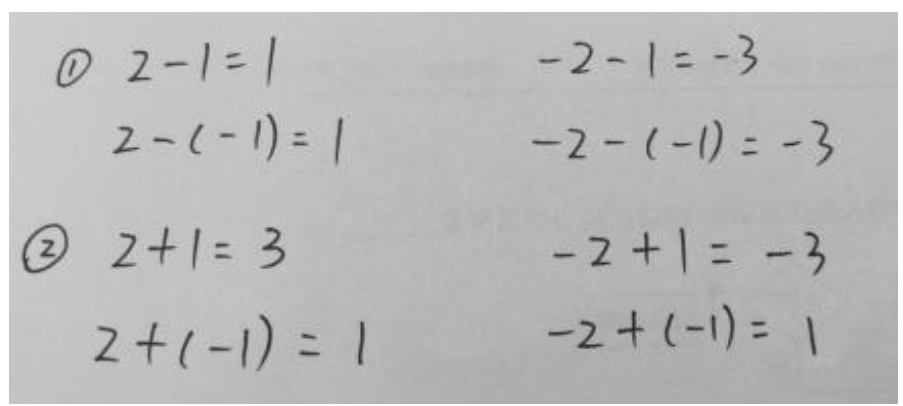

Fig. 1. Calculation of rational numbers

It can be seen from Fig. 1 that students have no errors in the addition and subtraction of positive numbers. When there are negative numbers, the students have made calculation errors. Students did not understand the meaning of "negative to negative" when calculating a negative number, resulting in the same answer as subtracting a positive number; when adding two negative numbers, they did not understand the extraction of the same sign The absolute values of the two numbers are added. The difficulties encountered by students in performing rational number operations are shown in Table 5. 
Table 5. Assessment result from Material Expert

\begin{tabular}{cccc}
\hline No. & Findings & Number of Students & $\begin{array}{c}\text { Percentage } \\
(\%)\end{array}$ \\
\hline 1. & Understanding the definition & 7 & 23.33 \\
2. & Explaining how to solve a problem & 20 & 66.66 \\
3. & How to make problem solving process & 12 & 40.00 \\
4. & Evaluate the outcome of problem solving & 9 & 30.00 \\
\hline
\end{tabular}

It can be seen from Table 5. that students are faced with doubts when solving rational arithmetic problems. Using hawgent dynamic math software for auxiliary teaching can help students solve the problems they face. When making a learning model, there are several points to remember, such as a) hawgent should enable students to more actively understand the concept of rational number addition and subtraction; b) hawgent should clearly describe the process of rational number addition and subtraction; c) hawgent It should be able to explain the relationship between rational number addition and subtraction; d) hawgent should be able to clearly and correctly show the problem solving process from the beginning to the end, and e) hawgent should be able to give different simple solutions.

The researchers plan to use hawgent dynamic math software to create a learning model of rational number addition and subtraction based on the problems faced by the students. This plan is designed to transform Polia's four-step problem solving into a flowchart, so that we can clearly see that the learning strategy using hawgent is achievable, which can help students understand how to add and subtract rational numbers.

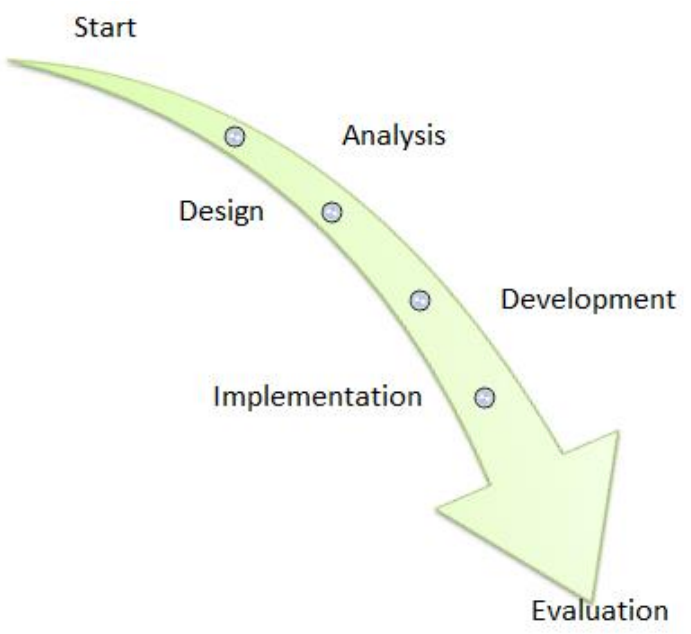

Fig. 2. Steps to make the learning media (ADDIE model)

In Fig.2, we can see from the analysis stage that the researchers collected data on student problems, which then became important information for making rational number addition and subtraction learning models using hawgent dynamic math software. In the planning stage, researchers use hawgent dynamic mathematics software to make learning models according to the needs of students and teachers, which are verified by media and materials experts. Researchers will continue to develop learning media until they are ready for implementation.

After making learning media using hawgent dynamic math software, the responses and inputs of teachers, media and materials experts are shown in Table 6.

Table 6. Responds from media and material experts.

\begin{tabular}{cc}
\hline Response & description \\
\hline Media expert & Add more pictures and animation \\
& The display must be made clear \\
Materialexpert & The media need to focus on the concept of addition and substraction \\
\hline
\end{tabular}


According to the answers and inputs of teachers, media and materials experts, Table 6 requires that learning media be simplified and clarified according to the arithmetic process of adding and subtracting rational numbers, and introduce dynamic teaching situations.

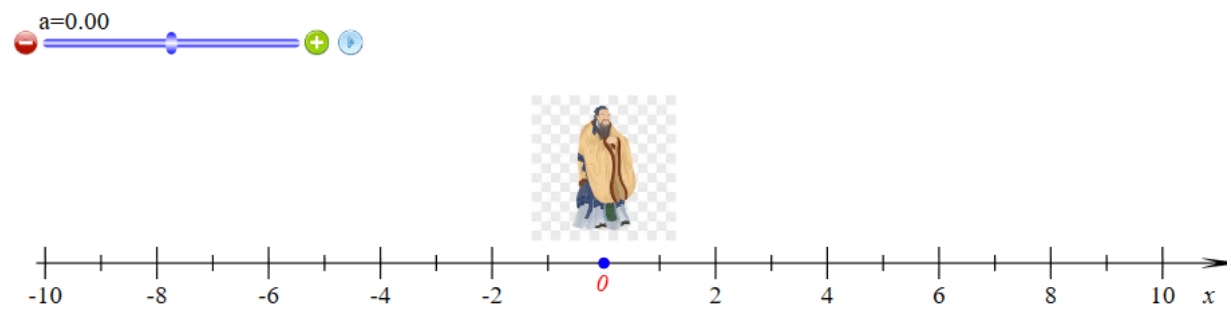

Fig. 3. Rational number operation with dynamic mathematical software of hawgent

Fig.3 presents a dynamic image of Confucius moving left and right on the number axis. When learning the addition and subtraction of rational numbers, students will feel boring. This dynamic situation mobilizes students' enthusiasm for learning. Drag the slider in the upper left corner, the image of Confucius will change accordingly. For example, the teacher asked: After Confucius walked forward two units and walked one unit backward, where would he stop? After Confucius moved forward two units, and then walked one unit in the opposite direction to the negative direction, how could it be expressed? These two problems can help students to solve them easily by using hawgent dynamic math software. Going forward is addition, and going backward is subtraction. By dragging the slider to let Confucius complete the steps of these two problems, it helps students solve the confusion of "negative to negative" in Fig.1, that is, they do not understand "going and negative The opposite direction walks one unit "means. In addition, hawgent dynamic math software has the characteristics of strong interest, easy to understand, and strong interactivity. After realizing dynamic teaching, students responded to hawgent dynamic math software with the theme of rational number addition and subtraction. Five of the 30 students were interviewed and expressed their opinions on the learning media. The results are shown in the Table.7.

Table 7. Responds from media and material experts.

\begin{tabular}{cc}
\hline Student & Response \\
\hline $\mathrm{T}-1$ & Hawgent is easy to use \\
& hawgent will help me teach theory \\
& I see students prefer classes with software \\
& The students are very excited and lively, \\
& I will use Hawgent for other classes in the future \\
\hline
\end{tabular}

Students try to use hawgent dynamic math software on their own, so that they can use the learning software to help solve when they have doubts about rational arithmetic. In this way, students can express their opinions and opinions on hawgent dynamic math software. Finally, the teacher interviewed 3 students and gave their input and opinions, (Table 8) on the hawgent dynamic math software.

Table 8. Students' interview result

\begin{tabular}{|c|c|}
\hline Question & Responses \\
\hline \multirow{3}{*}{$\begin{array}{l}\text { Is hawgent helpful in solving trigonometry } \\
\text { problems? }\end{array}$} & Very helpful \\
\hline & It makes the problem easier to understand \\
\hline & $\begin{array}{l}\text { Very helpful. I hope that other mathematics topic can be made } \\
\text { using hawgent }\end{array}$ \\
\hline \multirow{3}{*}{$\begin{array}{l}\text { What do you think about hawgent dynamic } \\
\text { mathematic software? }\end{array}$} & Hawgent can help solve mathematics problems \\
\hline & Hawgent are made for students to learn \\
\hline & Hawgent is very flexible and very good \\
\hline What are the weakness of the media & The language is not universal \\
\hline
\end{tabular}




\section{Conclusion}

Based on the above research, hawgent triangular dynamic mathematics software can be applied to seventh grade students. This can be seen from the ratings of media material experts, which are $85 \%$ and $84 \%$ respectively. We can also see that hawgent dynamic math software has received positive responses from students from the beginning to the end of the learning process, mobilizing students' enthusiasm for learning mathematics. Suggestions that were delivered based on the research result is that other mathematics topic needs a learning media such as Hawgent dynamic mathematics software to help teachers explain the basic concept.

\section{Acknowledgment}

We would like to thank to Guangxi Normal University for the research fund which has been given to the researcher. In 2019, Guangxi Higher Education Undergraduate Teaching Reform Project "research and practice of effective mathematics teaching guided by systematic thinking ability" (Project No.: 2019JGZ110); in 2020, Guangxi Graduate Education Innovation Plan Project "Research on training mode of improving high-level thinking ability" (Project No.: XJGY2020010)

\section{References}

[1] Aminah, S., Wijaya, T. T., \& Yuspriyati, D. (2018). Analisis Kemampuan Komunikasi Matematis Siswa Kelas Viii Pada Materi Himpunan. Jurnal Cendekia : Jurnal Pendidikan Matematika, 2(1), 15-22, doi: 10.31004/cendekia.v2i1.29.

[2] Andini, D., Mulyani, N., Wijaya, T., \& Supriyati, D. (2018). Meningkatkan Kemampuan Komunikasi Matematis Dan Self Confidence Siswa Menggunakan Pendekatan PBL Berbantuan Geogebra. Jurnal Derivat: Jurnal Matematika Dan Pendidikan Matematika, 5(1), 82-93, available at: Google Scholar.

[3] Wijaya, T. T., Dewi, N. S. S., Fauziah, I. R., \& Afrilianto, M. (2018). Analisis Kemampuan Pemahaman Matematis Siswa Kelas IX Pada Materi Bangun Ruang. UNION: Jurnal Ilmiah Pendidikan Matematika, 6(1), 19-28, doi: 10.30738/.v6i1.2076.

[4] Dini, M., Wijaya, T. T., \& Sugandi, A. I. (2018). Pengaruh Self Confidence Terhadap Kemampuan Pemahaman Matematik Siswa Smp. Jurnal Silogisme, 3(1), 1-7, doi: 10.24269/js.v3i1.936.

[5] Badraeni, N., Pamungkas, R. A., Hidayat, W., Rohaeti, E. E., Wijaya, T. T., Sudirman, J. J., \& Barat, J. (2020). Analisis kesulitan siswa berdasarkan kemampuan pemahaman matematik dalam mengerjakan soal pada materi bangun ruang sisi datar. 04(01), 247-253, doi: 10.31004/cendekia.v4i1.195.

[6] Kulsum, S. I., Hidayat, W., Wijaya, T. T., \& Kumala, J. (2019). ANALYSIS ON HIGH SCHOOL STUDENTS ' MATHEMATICAL. Jurnal Cendekia : Jurnal Pendidikan Matematika, 03(02), 431-436, doi: 10.31004/cendekia.v3i2.

[7] Badriyah, L. (2017). Analisis kesalahan dan scaffolding siswa berkemampuan rendah dalam menyelesaikan operasi tambah dan kurang bilangan bulat. Jurnal Pendidikan: Teori, Penelitian, Dan Pengembangan, 2(1), 50-57. available at: Google Scholar.

[8] Nurjannah, N., Danial, D., \& Fitriani, F. (2019). Diagnostik Kesulitan Belajar Matematika Siswa Sekolah Dasar Pada Materi Operasi Hitung Bilangan Bulat Negatif. DIDAKTIKA : Jurnal Kependidikan, 13(1), 68-79, doi: 10.30863/didaktika.v13i1.340

[9] Cunhua, L., Ying, Z., Qunzhuang, O., \& Wijaya, T. T. (2019). MATHEMATICS COURSE DESIGN BASED ON SIX QUESTIONS COGNITIVE THEORY USING HAWGENT DYNAMIC MATHEMATIC. Journal On Education, 02(01), 36-44, available at: Google Scholar.

[10] Wijaya, T. T., Ying, Z., \& Purnama, A. (2020). THE EMPIRICAL RESEARCH OF HAWGENT DYNAMIC MATHEMATICS TECHNOLOGY INTEGRATED INTO TEACHING. Journal Cendekia: Jurnal Pendidikan Matematika, 04(01), 144-150, doi: 10.31004/cendekia.v4i1.174.

[11] Abadi, M. K., Asih, E. C. M., \& Jupri, A. (2018). The Development of Interactive Mathematics Learning Material Based on Local Wisdom with .swf Format. Journal of Physics: Conference Series, 1013(1), doi: 10.1088/1742-6596/1013/1/012131. 
[12]Bernard, M., Sumarna, A., Rolina, R., \& Akbar, P. (2019). Development of high school student work sheets using VBA for microsoft word trigonometry materials. Journal of Physics: Conference Series, 1315(1), doi: 10.1088/1742-6596/1315/1/012031.

[13] Kristanto, A., Mustaji, Mariono, A., Sulistiowati, \& Nuryati, D. W. (2018). Developing Media Module Proposed to Editor in Editorial Division. Journal of Physics: Conference Series, 947(1), doi: 10.1088/17426596/947/1/012054.

[14]Zainuddin, Hasanah, A. R., Salam, M. A., Misbah, \& Mahtari, S. (2019). Developing the interactive multimedia in physics learning. Journal of Physics: Conference Series, 1171(1), doi: 10.1088/17426596/1171/1/012019. 